Volume 1 Number 2

\title{
SOCIAL MEDIA USE AND POLITICAL COMMUNICATION CHALLENGES AMONG SELECTED ENTREPRENEURS IN NIGERIA
}

\author{
Doris Ngozi Morah, $\mathrm{PhD}$ \\ Department of Mass Communication, \\ Madonna University, Okija. \\ morahng@yahoo.com; \\ ORCID iD: https://orcid.org/0000-0002-7854-3238 \\ 08064810290 \\ Chinwe Elizabeth Uzochukwu, PhD \\ Department of Mass Communication, \\ Nnamdi Azikiwe University, Awka, Nigeria. \\ Mail: ce.uzochukwu@unizik.edu.ng \\ 08037917259
}

\begin{abstract}
Social media technology has become 'the mouth-piece' of the millennium, especially in Nigeria and Africa. It provides the much-needed oxygen for universal democratisation processes and considered as most suitable for expression of opinion on public issues, affairs and debates. Though its impacts are still incipient, it is palpable that social media platforms promote a new public sphere for negotiation between political, national, public and cultural interests, especially in Nigeria. The survey investigates how entrepreneurs are using social media to participate in governance actively and inherent challenges hinged on Technology Determinism and Agenda Setting theories. Deploying purposive sampling, to select 200 respondents from Enugu and Anambra States of Nigeria, findings show that social media, especially Facebook, Twitter and Whatsapp augment interest, participation, interaction and socialisation among artisans and traders with regards to politics to a great extent. The findings, however, contrast the notion that media literacy is a barrier to social media use, which assumes that uneducated people may not be able to manipulate social media effectively. Results also demonstrate that social media could be an excellent strategy for futuristic political development in selected cities. The study, therefore, recommends a decrease in the cost of data tariff to enable artisans and traders, especially the rural-based entrepreneurs have access to the Internet and social media.
\end{abstract}

Keywords: Political Communication, Social Media, Media Use, Entrepreneurship, Nigeria, Democracy

\section{INTRODUCTION}

Citizens of every country have not only the potential but also the right to express their ideas and opinions worldwide through the new media, especially on social media. While talking about new media, it is apt to understand that what is an "old" or "traditional" media for the advanced societies may, for other regions, be a revolutionary new in its use - such as the community radio in India. The new media and access to them remain critical tools for democracies to correct themselves (Morah, Ekwenchi \& Chiaha, 2019) and for citizens to become aware of their government's abuses and violations of human rights, and the right to be informed. Swanson and Mancini (1996) observe that "election campaigns are critical periods in the lives of democracies. They select decision-makers, shape policy, distribute power and provide venues for debate and socially approved expressions of conflict about factional grievances and issues". 
There is no doubt that Internet penetration, has expanded in the last two decades, especially in Africa and Nigeria. Globally the Internet penetration rate as of June 2019, according to Internetworldstats report (2019) was 4422,494,622 while that of Africa was 525, 148631. For Nigeria, with an estimated population of 200, 962, 417, as of June 2019, there is a massive transformation in internet use. The penetration rate increased sharply from 200,000 in 2000 to 123, 486615 in 2019. The significant gap in the figures is a clear indication that most Nigerians became more Internet-hungry and conscious; probably because of the pervasiveness and disruptiveness of the new media technology. Social media, which is a new media offspring, however, ballooned over the past few years. Though Facebook has grown exponentially since 2006 worldwide, the leading global social networking site according to reports on (napoleoncat.com) has 22960000 users in Nigeria users who are 11.2\% penetration rate of the Nigerian population as of December 2018. Majority of them were men $(61.7 \%)$ demarcated within people aged 25 to 34 ; while the largest user group are young people within 18 to 24 years comprising 7800000 people. The report indicates that women had a total of $38.3 \%$ user only (https://napoleoncat.com)

The use of the new media technology in delivering campaign messages to voters during elections is not only critical to political parties and candidates but also in the election campaign process as social media is now affecting political campaigns. It plays a crucial role in informing the public about politics, campaigns and elections. Social media also influences what issues voters should care about in elections and what criteria they should use to evaluate candidates. In the past, traditional media in the forms of Newspapers, TV, Radio, billboards and printed material, such as pamphlets and letters were indispensable tools for delivering credible forms of political campaign messages despite their shortcomings of direct communication. The traditional media has intense competitions with social media, especially Facebook and Twitter. For instance, Smith (2011) found that one in five adults (22\%) who were online used Twitter or a social networking site to make political decisions in 2010. Morah, Udeze and Ekwenchi $(2019$, p.8) establish that preponderance respondents $(67.9 \%)$ reacted positively to the 2015 election results disseminated through Facebook in Nigeria. The preceding demonstrates a firm reliance on social media for political engagement.

Kushin and Yamamoto (2010) also argue that the growth of online political behaviour is aided partly by the recent emergence of new interactive, media-rich websites. The social media transformation initiated by new media in the political environment has globally impacted substantially on political campaigning. It is stimulating a move towards a more interactive form of campaigning, with politicians being in direct contact with constituents via different platforms of social media. Haynes (2008) collaborates that new media are presently the leading innovation for presidential candidates, just like radio and television and computerised databases revolutionised the election process in earlier decades. Cary (2010) also agrees that Internet restructures how Americans do everything-including electing their leaders. The author thinks political candidates who would have had no chance before the Internet can now overcome tremendous odds; with people, they energise serving as the backbone of their campaign. This viewpoint propelled the trajectory of the study on social media use of selected entrepreneurs in selected cities in Nigeria with a concentration on their political decisions and activities.

\section{THE PROBLEM AND OBJECTIVES}

Social media platforms like Facebook enable users to create pro connections with friends and acquaintances online. Some level of media to manipulate social media platforms and the Internet. The condition equa 
microblogs, and video sharing sites, among others. For all social media sites and platforms, an underlying commonality is a user-generated element characterised by openness and collaboration enabled by media literacy. Therefore, due to the opportunity offered to people to express political views and opinions online the social media plays a vital role in political campaigns. However, there exists little knowledge on the extent and pattern of use of social media among Nigerian artisans and traders with regards to political communication. Social media allow users to not only seek information but also interact with others through online expression such as posting political commentaries on blogs and social network sites and sharing multimedia commentary (Kushin and Yamamoto, 2010). It also makes the polity to acquire information and governmental communication for political empowerment (Duru \& Morah, 2015; Morah, Udeze \& Ekwenchi, 2019).

Therefore, effective use of social media for political purpose should require some level of media literacy and media availability. This study will be relevant in examining the adoption of social media among traders and artisans as a popular tool in terms of its potentialities, issues and role in political development in Nigeria. The following objectives inform what the study sets out to achieve:

$>$ To determine how Nigerian entrepreneurs are using social media for political participation.

$>$ To examine how social media are initiating new political sphere among selected entrepreneurs.

$>$ To identify challenges faced by entrepreneurs in the use of social media in politics.

\section{Research Questions}

$>$ RQ1: How are Nigerians entrepreneurs using social media in political participation?

$>$ RQ2: To what extent is the social media, initiating new political sphere among selected entrepreneurs?

$>$ RQ3: What challenges are faced by Nigerians entrepreneurs in the use of social media in politics?

\section{THEORETICAL FRAMEWORK}

The Technology Determinism and the Agenda-Setting theories formed the theoretical basis for this study. Mcluhan's (1962) Technology Determinism theory states that media technology shapes how individuals in a society think, feel, act; and how society operates as there is a transition from one technological age to another. In essence, people learn and feel and think the way they do because of the messages received through the most current and available technology (social media). The theory further explains that when new systems of technology are developed, the culture or society is immediately changed to reflect the senses needed to use the new technology. It predicts that with every new system of media technology, society will change and adapt to that technology. There is a simple cause and effect analysis between the introduction of new technology and the changes in society's way of thinking, feeling, acting, or believing. Since humans do not have much free will at all, whatever society as a whole is using to communicate, people will alway people will quickly adapt to social media which is vague in today's pol interactivity and more democratic participation (Morah \& Uzochukwu, 2

Theorists Maxwell McCombs and Donald L. Shaw propounded the Ag which states that the media (mainly the news media) are not always 
people what to think, but specifically, what to think about each day. The agenda-setting process is an almost unavoidable part of newsgathering by the large organisations which make up much of the mass media. Stuart Hall points out that some media organisations are accorded a high degree of respect and authority because they produce contents which are often competent, impartial and severe. The public is bribed with good radio, television and newspapers contents into an acceptance of the biased, the misleading, and the status quo through the agenda-setting process.

The media are not, according to this approach, crude agents of propaganda. The interpretations provided by media, in the long run, are the most preferred by, and least challenging to those with economic power. Greg Philo demonstrates the reality of the preceding in his 1991 article, "Seeing is Believing". He showed that recollections of the 1984 UK miners' strike strongly correlated with the media presentation of the event, including the perception of the picketing as mainly violent when violence was rare; and the use by the public of phrases which had appeared originally in the media. Therefore the use of social media could help set some agenda for people in a developing economy like Nigeria. Social media is presently setting an agenda for the world, unbridled, including political agendas (Morah, Ekwenchi \&Chiaha, 2019).

\section{SOCIAL MEDIA AND GLOBAL POLITICAL CAMPAIGNS}

Political campaigns have existed as long as there have been informed citizens about campaigning objectives. Politicians seeking victory at the elections need to persuade and convince the electorate in order to win their votes. It is now commonplace for politicians to use new media technology like social media in announcing their interest to vie for elective positions. Politicians, therefore, employ several channels of persuasive and interactive communication, including the new social media to communicate with their constituent and the electorates. The use of social media in political campaigns has drastically changed the momentum of politics all over the world.

Studies reveal that citizens increasingly use media technologies such as the Internet and social media to learn about political campaigns, follow the news, and engage in political activities by volunteering, donating funds, or researching public policy options (Morah, Udeze \& Ekwenchi, 2019; Morah \& Uzochukwu, 2019; Howard, 2005; Hamilton, 2011). Political parties are becoming more aware of these new trends, and politicians are increasingly making use of social media tools for political campaigns, to make campaign announcements and to communicate with potential voters. YouTube and Facebook potentialities enable updates of voter's registration, political campaigns and debates, while Twitter is used for personal views and opinions about candidates, political parties and their ideologies. Today, every politician in Nigeria has at least one social media account which they treasure as their mouth-pieces and selling points.

During political campaigns, social media platforms provide real live political rallies and party conventions online, such that supporters who cannot participate physically are considered at a reduced cost. Even the media industry appreciates the potentials of elections as the use of social media has made non-professional jo commentators to become alternative commentators and opinion leaders in through blogging and citizen journalism (Bruns, Saunders, Wilson, 2007 candidates have provided notable cases in new media use for election can States Presidential campaign in 1996 of President Bill Clinton and Bob first campaigns that utilised the Internet on a national level. Howard De 
Democratic presidential nomination offered a glimpse into what Internet campaigning was capable of producing. His use of the Internet leads to his rise to fame. Again, during the 2008 United States Presidential election between John McCain and Barack Obama, the Internet was extensively utilised by both candidates. Barack Obama's extensive use of the Internet during his campaigns earned him the name the King of Social Networking by the Washington Post.

Evans (2008) succinctly demonstrates the extent of politician's engagement on social media during the 2008 USA election's political campaign. He argues that in the US primary elections, both Hilary Clinton and Barack Obama utilised social networking sites to a great extent. Clinton however, only employed the main sites, including Facebook, Twitter and YouTube, to speak in communities, rather than making use of their full potential and engaging with her audience. Obama, on the other hand, operated at this engaged level, using Facebook, Twitter and YouTube page and niche community sites such as Faith-based and Glee. Obama reached out to individual groups in society including African American, Asian, Latino and religious-based communities. He was able to successfully tap into these communities where they were often more passionate and dedicated about particular causes (Evans, 2008).

President Barack Obama's 2008 presidential campaign, however, changed the way political campaigns utilised the Internet, specifically the social media, for political purposes. According to an April 4, 2011 article on the political blog ( Politico), Obama brought the long-promised political power of the Internet to bear on a presidential campaign, raising millions and organising thousands through a groundbreaking website and massive email list (Tau, 2011). Obama's use of social media in the 2008 campaign compared to former President John F. Kennedy's use of television. The election of Barack Obama as president was notable than others in history because he used the new media that has forever changed politics. Miller (2008) posits that both leaders initiated a new paradigm in political communication as Mr Kennedy, used television while Mr Obama, explored the Internet. In addition to using email and a website, Obama concentrated on social media use to mobilise volunteers and reach young voters (Graber, 2010, p.194).

\section{SOCIAL MEDIA USE IN AFRICAN POLITICS}

Social media generally used as a primary platform for disseminating information has undoubtedly become a powerful political communication tool in Africa and Nigeria is not an exception. It allows candidates and their party's privilege to reach larger audiences in shorter periods than the traditional mass media used formerly. Political candidates and parties use social media platforms for political campaign purposes, to drum up support for various candidates seeking positions in government and to publicise their manifestos and promote political party ideologies. Social media play useful and significant roles not only for mobilising voters but also in integrating all other facets of campaigns, including rally, organising and delivering campaign messages to potential voters consistently, at relatively no cost (Morah \&Uzochukwu, 2019).

In the Nigerian political terrain, the new media of the Internet and social media appeared to be playing a massive role in shaping the country's political landscape. President Goodluck Jonathan made history as the first head of government to use Facebook to make his formal declaration to stand for election. The president's decision changed the political tide in election matters in the country. In the same vein, other politicians in the country also made concerted efforts to gain electoral relevance via the Internet, Facebook and Twitter. Although only a 
Volume 1 Number 2

small percentage of the Nigerian electorate then possesses their computers, many people used internet cafes and increasingly mobile phones to go online and get political updates. The politicians also used social networking sites to leverage the younger generation and harnessed new phases in the country's online revolution.

The 2011 Nigerian general election witnessed the use of social media to announce the intention of the Nigerian presidential candidates, Goodluck Jonathan, to run for the presidential seat and to campaign during the election extensively. Also, other aspirants: Muhammadu Buhari of the Congress for Progressive Change (CPC) and Nuhu Ribadu of the Action Congress of Nigeria (ACN) used social media extensively. The use of social media had a significant influence in the subsequent elections of 2015 and 2019 in Nigeria. In Tanzanian, presidential candidate, Jakaya Mrisho Kikwete, in the 2010 general election also used social media. Since global leaders achieved political successes with social media adoption in campaigns and governance, empirical insight into the extent of social media use in Nigeria among artisans and trader will help appreciate its essence in African grassroots politics.

\section{METHODOLOGY}

The research design employed in the study was the survey method. This method was adopted because it is suitable for examining issues in social media use in politics and for eliciting the response of the residents of Awka and Enugu metropolises concerning the objectives of this study. Survey research was, therefore, essential in collecting data for a population too large to be observed directly. The study adopted the questionnaire as a measuring instrument, while SPSS version 19 and the simple frequencies figures and percentages were utilised for data analysis.

\section{Population and Sampling Technique}

The population of the study comprises residents of Anambra and Enugu State out of which a sample of 200 was drawn from Awka and Enugu metropolises through purposive sampling technique to represent this population. This choice emerges because there is always a heavy concentration of potential voters who are entrepreneurs in the two major cities. Purposive sampling was, therefore, deployed to select only 200 artisans and traders resident in the two cities in an equal ratio of 1:1 to attain the purpose of the study. The two purposively selected cities of Awka and Enugu are in Anambra and Enugu states respectively and found in the Southern part of Nigeria. They are predominantly of the Igbo extractions and are mainly business people and entrepreneurs.

\section{DATA ANALYSIS AND DISCUSSION}

Data for this analysis was collected from a sample of 200 residents of Awka and Enugu metropolises who are artisans and traders. A response rate of ninety-eight per cent recorded; that is, 196 copies of questionnaires were completed and returned.

Table 1: Demographic Patterns of Respondents

Age

Variable

Frequency

$\%$ 
$18-24$

25-34

$35-44$

$45-54$

$55-66$

$65+$

Total

Sex

Male

Female

Total
45

68

30

18

12

23

196

105

91

196
23

35

15

9

6

12

$100 \%$

54

46

$100 \%$

The demographic data presented in Table1 indicate that out of the sampled population for the study, 54 per cent of the respondents were males, while 46 per cent of the respondents were females. The finding affirms research (Morah \& Omojola, 2018) that more males are entrepreneurs in Nigeria than females. Males are more likely to be interested in politics than females.

In terms of the age distribution of the respondents, 35 per cent of the respondents were 25-34 years, 23 per cent were 18-24 years, while 15 per cent constitute respondents within age brackets 35-44 years. The finding implies that most of the respondents are young people aged 18- 34 years. These respondents are regarded as millennial and are most likely to use social media technology for political engagement more than other age brackets.

Other tables generated in this study were used to answer the various research questions raised in the study. For research question one that sought to find out if the Nigerians/audience uses the new media to participate in politics actively, responses on Table 2 provided the answer.

RQ1: How are Nigerians entrepreneurs using social media in political participation?

Table 2: Frequency of social media use in political participation

$\begin{array}{lll}\text { Response } & \text { Frequency } & \% \\ \text { Always } & 102 & 52 \\ \text { Often } & 68 & 34.6 \\ \text { Sometimes } & 16 & 8.2 \\ \text { Rarely } & 5 & 2.6 \\ \text { Never } & 5 & 2.6 \\ \text { Total } & 196 & 100\end{array}$

Data on Table 2 shows that a majority of 170 respondents $(86.6 \%)$ mostly use social media to participate and get political information. The finding implies that entrepreneurs are conversant with the application of social media, which influence their interest in use and fall in line with Morah \&Uzochukwu (2019). The finding further affirms the assumptions of Technology Determinism theory.

Table 3: Social media use and active participation in politics 
Volume 1 Number 2

$\begin{array}{lll}\text { Response } & \text { Frequency } & \% \\ \text { Agree } & 84 & 43 \\ \text { Strongly Agree } & 68 & 35 \\ \text { Disagree } & 34 & 17 \\ \text { Strongly disagree } & 10 & 5 \\ \text { Total } & 196 & 100\end{array}$

In Table 3, the result of the survey shows that majority of the respondents (78\%) agree that social media make them participate actively in politics. The above is a reflection of both high internet penetration and acceptance of the social media in Nigeria as a futuristic means of political engagement. The finding corroborates data on Table 2 and attests the findings of Morah, Udeze \& Ekwenchi (2019). It is, thus, plausible that given the political space, most Nigerians entrepreneurs are likely to have increased active participation in politics and governance in the next five years.

RQ2: To what extent is the social media, initiating new political sphere among selected entrepreneurs?

Table 4: Social media and promotion of interactivity and understanding about politics

$\begin{array}{lll}\text { Response } & \text { Frequency } & \% \\ \text { Yes } & 127 & 65 \\ \text { No } & 69 & 35 \\ \text { Total } & 196 & 100\end{array}$

Data on Table 4 indicates that the majority (65\%) of the respondents agree that social media promotes interactivity and understanding about Nigerian politics. This finding implies that, even though the social media dramatically plays a role in political development in Nigeria, its ability to stimulate interaction and improve the understanding of politics has not been fully achieved among selected entrepreneurs in Nigeria. The real-time interaction, most often possible with social media, makes it attractive as a tool for political communication. The finding is a deviation from the findings of Morah \&Uzochukwu (2019) that found small and medium scale entrepreneurs mostly using Whatsapp for commercial purposes.

Table 5: Potentialities of social media as a tool for political development

$\begin{array}{lll}\text { Response } & \text { frequency } & \text { Percent } \\ \text { Necessary for political development } & 67 & 34 \\ \text { Not necessary } & 78 & 40 \\ \text { To an extent, important } & 45 & 23 \\ \text { No opinion } & 6 & 3 \\ \text { Total } & 196 & 100\end{array}$

The potentialities of social media as a veritable tool for political development, according to Table 5, is yet to be appreciated by a good number of respondents (40\%). However, 34 and $23 \%$ of the respondents think that social media is necessary and to an extent significant respectively, for political development. The finding, therefore, showed respondents (57\%) regard social media as an indispensable tool for po Further probe shows that selected respondents mostly prefer using Whatsapp for political communication and news because of the feature The findings further substantiate https://napoleoncat.com report on con 
Volume 1 Number 2

Nigeria. It is reasonable to see Nigerians as a people eager to affect the political process using new media technology such as social media platforms.

RQ3: What challenges are faced by Nigerians entrepreneurs in the use of social media for political communication?

Table 6: Challenges in Social media by Nigerian entrepreneurs

Variables

High Tariff cost Frequency

97

50

30

Availability of technology

Media Literacy

No Idea

Total

$\begin{array}{ll}15 & 7.7 \\ 4 & 2 \\ 196 & 100\end{array}$

$\%$

49.5

25.5

15.3

100

Responses on Table 6 demonstrate that significant challenges to effective use of social media among artisans and traders for political development are high tariff cost $(49.5 \%)$ and connectivity issues $(25.5 \%)$. Availability of technology $(15.3 \%)$ was mentioned as another obstacle; while media literacy $(7.7 \%)$ was the least challenge to social media adoptions among selected entrepreneurs. The finding here implies that media literacy is no longer a serious threat to the internet and social media usage in Nigeria. Table 6 data is in agreement with the 2019 www.internetworldstats.com report on African internet penetration and demonstrate that the media are setting exciting political agendas for Nigerians.

Table 7: Dispositions of respondents toward the utilisation of social media

$\begin{array}{lll}\text { Response } & \text { Frequency } & \text { Percent } \\ \text { Positive } & 90 & 46 \\ \text { Negative } & 54 & 28 \\ \text { Indifferent } & 30 & 15 \\ \text { No Idea } & 22 & 11 \\ \text { Total } & 196 & 100\end{array}$

Data on Table 7 indicates that a higher percentage of respondents $(46 \%)$ have a positive disposition towards the use of social media by politicians in Nigeria. While only $28 \%$ has a negative disposition, $15 \%$ of the respondents are indifferent to the use of social media by politicians in Nigeria. The results suggest that for social media to contribute substantially to the development of the political process in Nigeria, more work done in order to elicit more positive disposition to social media.

\section{Discussion of Findings}

The potentialities and challenges of social media use in politics have been demonstrated in the study. The expansion of social media in Nigeria, and its exploitative nature, should, therefore, be effectively manipulated in its use in a political campaign. Th social media effectively during the 2011 election, Nigerians were some his numerous Facebook messages resulting in the January 2012 fuel shook the PDP regime and queried the people's trust on the governm 2015, President Buhari could not control the freedom of speech enjoyed and on social media despite the proposal for anti-hate speech regulatio 
Bill and the Cyber Crime Act. These instances affirmed the finding that inadequate media literacy does not have a significant effect on social media usage in Nigeria. With most Nigerians having access to the Internet; discussion of the democratising potential of internetrelated social media technology seems not hurried. At present, political discussions online is a privilege for those with access to smart devices, computers and the Internet. Those who would benefit the most from the democratising potential of social media technology do not have much access to it. Much participation in political discussion helps but does not ensure a healthier democracy. Social media technology enhances increased, but not necessarily more diverse, participation in political discussion since they are still only available to a small fraction of the population.

Social media platform makes participation in the political sphere more convenient. Though they do not guarantee active participation, online political discussions are limited to those with access to computers and the Internet. Therefore, people without access to the Internet do not necessarily pursue political discussion. As a result, online discussions are mostly dominated by a few. While social media has the potential to advance the public sphere, at least in terms of the information that is available to citizens, only a few people are able or willing to take on the challenge. There abound cases of legal entanglement by individuals and governments on victims of perceived hate speeches online. Access to more information might not necessarily create more informed citizens or lead to more excellent political activity or ensure election victories. Even though access to information is useful to socialisation, the democratising potential of social media remains obvious as examined earlier. Also, responses from selected entrepreneur show that social media provides information on political matters and is therefore vital for political development in Nigeria. Though access to information is not universal and equal to all with mainstreams, social media allows freedom of speech and is proximal to people. Those who can access online information are guaranteed additional tools to be more active citizens and participants of the public sphere under the social media dispensation. The findings and literature demonstrate the tenets of the technology determinism theory and the agenda-setting theory. The study, therefore, situates on the words of Cary (2010): "Politicians have long sought to go around the mainstream press filter-from fireside chats, to whistle-stop tours, to snail-mail newsletters - but the new media take it a step further by even more directly connecting them with voters."

\section{CONCLUSION AND RECOMMENDATIONS}

The study concludes that selected artisans and traders in the two selected cities in South Eastern Nigeria use social media for political decision makings to a great extent. There are critical limits to the political influence of social media, however, as findings demonstrate. Social media is expected, for instance, to lose some of their disruptive impact as politicians and others learn to take better account of them. However, the researchers predict that social media will eventually become an increasingly pervasive tool through which politicians and others will seek to influence political debate soon. The implication of the paper so far remains that; social media is a two-sided sword that should be handled with care. The findings of this study are thus a beginning, not an end to social media studies.

The political consequences of social media are unlikely to be limite mechanisms explored here. Fortunately for political scientists, socia uniquely rich set of data exploited in order to explore a variety of Relevant research remains to be done, for example, on the consequence groups, Twitter groups and Instagram for political mobilisation, and regions of Nigeria and Africa. The study recommends a decrease in the 
Volume 1 Number 2

enable artisan and traders; especially the rural-based entrepreneurs have access to the Internet and social media. The study further recommends that the Nigerian government formulates a proactive regulation to control the abuse of social media in the country.

\section{REFERENCES}

Bruns, A; Wilson, J. \& Saunders, B (2007). Bloggers Watch as Journalists Turn on Each Other over Worm. ABC News Online: Club Bloggery, Australian Broadcasting Corporation. Retrieved from http://eprints.qut.edu.au

Cary, M.K. (2010). 5 ways new media are changing politics. US News. Retrieved from http://www.usnews.com/opinion/articles/2010/02/04/5-ways-new-media-arechanging-politics?

Duru, C. W. \& Morah, D. N. (2017). Effective Communication and the Implementation of Open Government Partnership (OGP) in Nigeria: Realities and Challenges. UniUyo Journal of Communication Studies, 1(1).

Evans, L. (2008). Barack Obama is rocking the youth vote. Search Engine Watch. Retrieved from http://searchenginewatch.com/3629136.

Facebook Users in Nigeria (December 2018). Retrieved from https://napoleoncat.com

Graber, D. A. (2010). Mass Media and American Politics (8th Ed). Washington, DC: CQ Press.

Greyes, N. (2011). "The untapped potential of social media: A primer for savvy campaigners". Campaigns and Elections, 300.

Haynes, A. (2008). Making an impression in the $21^{\text {st }}$ century: An examination of campaign use of new media in the 2008 presidential nomination campaign. Draft paper Department of Political Science, School of Public and International Affairs, University of Georgia.

Hamilton, S. (2011). Use of social media in presidential campaigns: Do social media have an effect on the political behaviour of voters aged 18-24? Honours Theses. (Paper 4)Roger Williams University.

Howard, P. N. (2005). New media campaigns and the managed citizen. Washington: Cambridge University Press.

$\begin{array}{llll}\text { Internet penetration in Africa. (June 2019). Retrieved } & \end{array}$ fromwww.internetworldstats.com/stats1.htm

Kushin, M. J. \& Yamamoto, M. (2010). Did social media really matter? College students use of online media and political decision making in the 2008 election. Mass Communication and Society, 13(5), 608-630. 
Volume 1 Number 2

Miller, C. C.(2008). How Obama's Internet campaign changed politics. New York Times Blogs. Retrieved from http://bits.blogs.nytimes.com/2008/11/07/howobamas-internetcampaign-changed politics/?pagemode $=$ print $\% 20>$.

Morah, D. N. \& Ekwenchi, O. C. (2019). Nigerian Undergraduates and Online Methodologies in Communication Research: Investigating the Expectation Paradigm. International Journal of Communication and Social Sciences, 1(1). 98-108.

Morah, D. N., Ekwenchi C. O. \& Chiaha A. I. (2019). Fears and Realities: Investigating Social Media Use for Sustainable Economic Development in Nigeria. Transdisciplinary Agora for Future Discussions Journal (TAFFD'S), 1(1), 22-33. https://www.magzter.com/US/TAFFDS,-Inc./Transdisciplinary-Agora-for-FutureDiscussions-Journal/Education/

Morah, D. N. \& Omojola O. (2018). Social Media Use and Entrepreneurship Development in Nigeria: Lagos and Onitsha in Focus. International Journal of Advance Study and Research Work, 1(5), 15-26.

Morah, D. N., Udeze, S. E., \& Ekwenchi, O. C. (2019). Online Engagements and Nigerian Polity: Exploring Users Reactions to Election Results on Facebook. International Journal of Advance Study and Research Work, 2(5), 1-11.

Morah, D. N. \& Uzochukwu, C. E. (2019). Nigeria's Social Media Culture: Exploring Civic Participation of Youths in the 2015 Presidential Election. International Journal of Advance Study and Research Work, 2(1), 1-12.

Smith, A. (2011). Reports: The Internet and campaign 2010. Pew Research Center's Internet and American Life Project. Retrieved from http://www.pewinternet.org/Reports/2011/The-Internet-and-Campaign-2010.aspx.

Swanson, D. \& Mancini, P. (1996). Politics, media and modern democracy: An international study of innovations in electoral campaigning and their consequences. Praeger, Connecticut.

Tau, B. (2011). Obama faces brave new web world. Politico. Retrieved from http://www.politico.com/news/stories/0311/51594.html. 